\title{
Theme-based Teaching Model Design in College English Teaching
}

\author{
Zheng Weiwei \\ Foreign Language Department \\ Jilin Business and Technology College \\ Changchun, China \\ 182076127@qq.com
}

\begin{abstract}
Firstly, the theme comes up with the conception of theme-based teaching. Theme-based teaching is from the level of life using dynamic forming conception to recognize classroom teaching and to construct classroom teaching in integrity. Secondly, it summarizes the application of theme-based teaching in practice and the existing problems. The key of teaching starts transferring. Thirdly, it puts forward the process of theme-based teaching model design which is proven to reform English teaching. By listening and reading, students get lots of language input about the theme. Through the ways of solving problems, simulating and so on, students autonomously and freely output language. At the same time, output of language has an opposite function on theme-based teaching. The recycling does not end until having a complete understanding of the theme. And it analyzes in detail with the example of 21 century college English reading and writing courses. At last, it concludes with the process of a case.
\end{abstract}

Keywords—college English teaching; theme-based teaching

\section{INTRODUCTION}

In 2004, education department issued made college English curriculum teaching demands. The teaching goal of college English is to develop students' English comprehensive application ability, making them communicate effectively in work and social communication. At the same time, enhancing students' independent learning ability and improving comprehensive cultural quality adjust to the needs of our economic development and international communication[1].

Students attending English language teaching programs are expected to acquire academic language skills as well as general language skills so that they can take part in their future courses effectively. However, most language programs may ignore academic English, to a large extent, focusing on general language skills and theory. These students are likely to commence their respective departments, lacking the essential academic language skill.

Dou Guimei thinks that theme-based teaching is from the level of life, uses dynamic forming conception to recognize classroom teaching and construct classroom teaching in integrity. Simply, it is an opening teaching, surrounding certain topic, fully emphasizing single person's experience, with the collision and integration of several texts, in the comprehension of concentrating on processes, to realize the curriculum theme meaning construction.
Haines(1989) thinks it is comprehensive reflection surrounding themes, not specific language skills' training. Theme-based teaching is a teaching mode surrounding the same theme link to cultivate English learners language comprehensive use abilities, and motivate language learning enthusiasm and interests[2].

College English theme-based teaching is under specific theme background to study texts comprehensively, deeply understand texts and have a further discuss about the related themes[3].

Zhejiang University's theme-based model reflects three important rules. The first rule is focusing on students and the key is to develop students' language comprehensive application ability; the second rule is to combine classroom teaching with extracurricular activities and the key point is to develop students' self-learning abilities; the third rule is to meet students' needs. Use students' active participation as standard. The mode really reflects the basic goal of improving their English application ability by guiding students to positively take part in language practice and making class become the important place of language practice.

The theme-based model of CBI may be a key to everybody's satisfaction while there remains ineffective use of academic English in the Turkish context(Sert, 2008). When the required language skills reported by the students were analyzed, it was seen that these language skills were mostly academic in nature. Therefore in thematic units we developed, the content was chosen according to students' interest and academic goals with a purpose to trigger their background knowledge (Stoller, 2002). In our study similar to that of Gianelli(1997) those students who studied theme-based units would no longer forget what they were studying because they became quite familiar with the content of the units. In addition Song(2006) attributes such an academic success of the students to the application of content-based ESL program. Similar to Song' study(2006) students in our study were also likely to achieve better academic results in their major studies due to theme-based instruction they received. In our study content-specific materials were used in the courses in the same way as Raphan and Moser(1994) used in their theme-based courses[7]

The teaching thoughts of model: (1)focus on students, and develop language comprehensive application ability; (2)class teaching focuses on the demands of students, use students' 
active participation as standard; (3)organic combination in and out of class, mainly to develop students' self-learning ability; (4)courses reflecting teaching thoughts and teaching model, serve the teaching purposes. The teaching model is a scientific teaching model, and it bases on meaning learning theory and constructivism learning theory[1].

\section{The APPliCATION OF THEME-BASED TEACHING}

Theme-based teaching's objective is themes, not knowledge system. Around themes, guide students autonomously to construct and develop knowledge structure[1]. It should be pointed that the changing of information and message is so fast that the capturing of information and message is so easy. Any texts' chosen theme is only a presupposed theme range and frame. Form relatively complete basic theme link, and get the foundation of theme introduction and discussion. When teachers guide students to learn essential theme content and related language points, it is not necessary to be confined to textbook contents. The capturing of teaching resources not only comes from texts and teaching references but also comes from all medias of modern society, such as newspapers, news, networks and so on. Based on using teachers' understanding of the themes, use all kinds of medias, especially networks, to collect the latest information about the themes, develop and stretch the themes, to make the reflection of the themes have more realistic significance.

In addition, in the choosing of language materials, because each unit is surrounding the same theme, textbooks are the formats of language materials and teaching contents. Although great masterpieces are through long ages and the words are standard, they are almost literature language and far different from the true language in real society communication. The students often can't use what they have learnt[6]. They choose the language materials which are modern, informative, visible, interesting and close to realistic life. The words are real, veritable, natural, and reasonable and can reflect abundant language phenomenon. The depth and width of vocabulary can be reflected. In addition, because language materials of each unit are made around the same theme, students can get lots of language input about the same theme when they are listening and reading. The frequency of repeat of words is high, which is not only beneficial to the language output of students when they are speaking, writing and interpreting, making them express themselves freely, but also beneficial to the accumulation, learning and using of language. Therefore, to this thematic, modern language material, students are happy to learn and use. And they are not only benefited by the practicality of language, but also benefited by the instructive function of language. And it can develop and improve students' language abilities largely.

This theme-based teaching model is proven to reform English teaching. The following is application model.

TABLE I. THE DIFFERENCE BETWEEN TRADITIONAL ENGLISH TEACHING AND THEME-BASED ENGLISH TEACHING

\begin{tabular}{|l|l|l|}
\hline Teaching Model & Subject & Key point \\
\hline Traditional English Teaching & Teachers & Teaching \\
\hline Theme-based English teaching & Students & studying \\
\hline
\end{tabular}

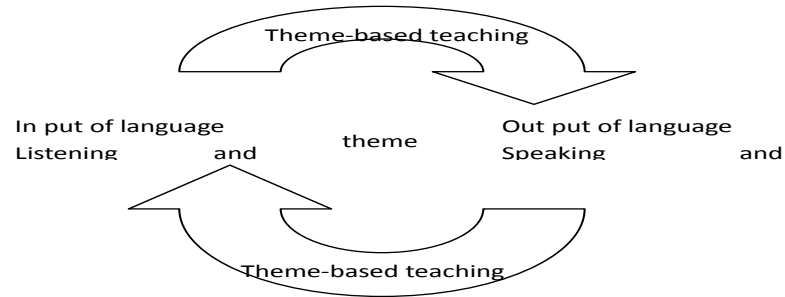

Fig. 1. Theme-based teaching model

By listening and reading, students get lots of meaningful, comprehensive language input which is about the same theme. Then through the ways of discussion, presentation, solving problems, simulating and so on, students participate fully, autonomously and freely in output language, to improve and exercise speaking, writing and translating skills. At the same time, output of language has an opposite function on themebased teaching. The recycling does not end until having a complete understanding of the theme. Table II shows that theme-based teaching is both useful and interesting to students.

TABLE II. STUDENTS' VIEWS OF THEME-BASED INSTRUCTION

\begin{tabular}{|l|l|}
\hline Students' views & Frequency \\
\hline thematic units were interesting and motivating & $94.7 \%$ \\
\hline $\begin{array}{l}\text { thematic units would be useful for future studies in } \\
\text { departments }\end{array}$ & $89.5 \%$ \\
\hline triggered background knowledge & $89.5 \%$ \\
\hline $\begin{array}{l}\text { learning English through both course books and thematic } \\
\text { units was useful }\end{array}$ & $84.2 \%$ \\
\hline
\end{tabular}

\section{The EXISTING Questions OF TheME-BAsed TEACHING}

Some teachers may worry that theme-based teaching mode and CET4/6 or any other English test are contradictory[2]. Because the objective of college English teaching has always been CET4/6. But the key of theme-based teaching is the structure of context, students' thinking ability and language expressing ability. So the key point of teaching starts transferring from words and expressions. This is the difference between theme-based teaching and traditional teaching mode. Traditional English teaching mode focuses on teachers, while theme-based teaching mode focuses on students. The change of teaching center is the problem to be solved. To make themebased teaching realize its purpose really, teachers need spend plenty of time and thoughts making the input of the theme really improve students' interest of learning and strengthen the input of related materials and design questions reasonably to make the students output the language materials in time. Therefore, teachers should be an active person of life, paying attention to the new things that happened lately in society, and knowing about students' life and thoughts. Giving up relaxing and accustomed teaching method or reducing researching time in order to give a good lesson, there must be some fighting in teachers' minds. Meanwhile, the requirement of students of theme-based teaching mode is high. Students have to preview forward. To start with, understand the meaning of the main text that is to study and memorize some key expressions. Moreover, to create an atmosphere in which students communicate with each other and dare to speak in class. The relaxing teaching method of teachers and biggest encouragement and acknowledgement to students are necessary. 
But some questions still need to be solved in this model. For example, students whose English is bad are not active in class performance. The monitor of autonomous learning is hard to carry out. Summative evaluation not only can't evaluate students' active activity participation, but also is bad for getting real feedback information. Therefore, we expect everyone struggle together, develop and improve the new teaching model.

\section{The Process of Design of Theme-Based Teaching}

Zhao Yan (2005) puts out that college English theme-based teaching mainly adopts the model: theme background introduces - text explain — text retell — theme discuss. He Hua(2009) focuses on the feature of new horizon college English course. The unit theme-based teaching model explored by the writer mainly includes five procedures: decide theme, set tasks, organize classroom activities, integrity teach and develop autonomous learning abilities.

Liu Xiao(2009), in her English teaching practice, the specific procedures of theme-based model are preview forward, lead-in questions, students' participation(debate; group discussion and presentation; role play; whole-class participation etc.) back to text.

The thesis introduces the theme based teaching mode design process with the example of 21 century college English. Each unit of 21 century college English reading and writing course contains three texts. Text $\mathrm{A}$ is a profound reading material, text $\mathrm{B}$ and text $\mathrm{C}$ are widely reading materials. The three texts are determined by one topic. Each unit begins with preview (which is a introduction of the unit) [4]. Firstly, select the theme of unit and know the background with the help of the preview before the unit. Then, introduce theme topics $\mathrm{A}, \mathrm{B}, \mathrm{C}$ and so on. Regarding topic A as profound material and topic B, $\mathrm{C}$ are learned by students themselves after class. Use prereading activities as cut points of topics and students have certain knowledge of topic during exercising. Then according to comprehension of text, reading analysis, and structured writing, students have certain knowledge of the structure of text. After that, through vocabulary, word building, structure, students have certain knowledge of strange vocabularies, expressions. At last, reading aloud lets students use spare time to read and recite to improve students' language feelings. Teachers can use text $\mathrm{B}$ and text $\mathrm{C}$ as the developing of theme; encourage students to select theme related knowledge. That is the basic process of theme-based learning and design.

\section{CASE OF DESIGN}

We use the text A of unit 1 in 21 century college English to design the theme based teaching model curriculum. Firstly, to introduce the theme background. The author of the article is Winston Churchill's (the theme character) daughter when the article was completed, Winston Churchill has died. Secondly, analyze the text. To begin with, analyze the structure of the text The whole text develops about Winston Churchill and his painting. Through lead-in the theme character (Winston Churchill)_leading in the theme topic 1(Why did he fall in love with painting?) — leading in the theme topic 1(He got an achievement in painting.) - topics ending. Next, in specific text analyzing, some theme unrelated vocabulary (adjective, adverb, prep etc.) need to be analyzed too. Because it has a close relationship with students' understanding of the theme meaning. Only to understand the meaning of the words, the deep meaning of the text can be understood. At last, to motivate students' learning interests and desires, the later activities continue. Firstly, after obtaining early knowledge structure about the theme, teachers should through the methods of questioning, thinking, and comparison guide students to discover knowledge blanks in original cognitive structure, regarding the sides of further discussing of one theme as new topic. Such as, the backgrounds of characters, the achievements of characters, the significance on history and so on. Students through autonomously checking materials, analyzing, and summarizing enrich the content of the theme. Then, let students complete one reading material of the same theme in limited time. Teachers organize students to debate and answer related reading comprehension questions. And at the same time, require them to complete 2 to 3 reading materials of same theme. Thus it is related to another teaching arrangement: reading by yourself, making them gets more related information, increase vocabulary and language materials around one theme.

TABLE III. DESIGN OF THEMATIC UNITS: WINSTON CHURCHILL--- HIS OTHER LIFE[7]

\begin{tabular}{|c|c|}
\hline 1. Warm-up: & $\begin{array}{l}\text { At the very beginning of the unit, students } \\
\text { examined some pictures. Having done this, in a } \\
\text { chart they wrote about what they know about } \\
\text { Winston Churchill and also what they wanted to } \\
\text { learn about Winston Churchill. }\end{array}$ \\
\hline 2. Pre-reading: & $\begin{array}{l}\text { Students got into groups and discussed what else } \\
\text { they want to learn about Winston Churchill. In } \\
\text { pairs they fill in the chart and with the rest of the } \\
\text { class they discussed what they wanted to learn } \\
\text { about Winston Churchill. }\end{array}$ \\
\hline 3. Reading for gist: & $\begin{array}{l}\text { Students read a text about Winston Churchill, } \\
\text { looking at the headings and matching them to } \\
\text { the paragraph numbers. }\end{array}$ \\
\hline 4. Detailed reading: & $\begin{array}{l}\text { Students read the text again and demonstrated } \\
\text { their understanding by using a chart. }\end{array}$ \\
\hline 5. Post-reading: & $\begin{array}{l}\text { After these activities, students read the passage } \\
\text { in the unit, and then studied unknown } \\
\text { vocabulary. Then, the students analyzed the text } \\
\text { using graphic organizers, and answered some } \\
\text { comprehension questions, which was followed } \\
\text { by vocabulary study. }\end{array}$ \\
\hline $\begin{array}{l}\text { 6. Vocabulary } \\
\text { building: }\end{array}$ & $\begin{array}{l}\text { Students were asked to make use of newly learnt } \\
\text { vocabulary about Winston Churchill in their } \\
\text { own sentences. }\end{array}$ \\
\hline $\begin{array}{l}\text { 7. Grammar } \\
\text { teaching: }\end{array}$ & $\begin{array}{l}\text { Having completed the reading and vocabulary } \\
\text { activities, the students studied the key } \\
\text { grammatical patterns, using the content in the } \\
\text { units. }\end{array}$ \\
\hline 8. Writing: & $\begin{array}{l}\text { Having finished grammar exercises, students } \\
\text { were asked to write about a given figure(Helen } \\
\text { Keller), then hand it in. }\end{array}$ \\
\hline 9. Speaking: & $\begin{array}{l}\text { Students read the extra information about } \\
\text { Winston Churchill and then talked about events } \\
\text { about him. }\end{array}$ \\
\hline $\begin{array}{l}\text { 10. Reading, listening } \\
\text { and speaking }\end{array}$ & $\begin{array}{l}\text { Students got into the groups as A and B. Group } \\
\text { A read Text B and group B read Text C. While } \\
\text { reading the texts, they made a note of the main } \\
\text { ideas and then talked about the text to their } \\
\text { friends. }\end{array}$ \\
\hline 11. Post reading & $\begin{array}{l}\text { Each student paired with a student from the } \\
\text { other group and told them about what they had } \\
\text { read. They listened to friends from the other } \\
\text { group and took notes. }\end{array}$ \\
\hline $\begin{array}{l}\text { 12. Culminating } \\
\text { Activity }\end{array}$ & $\begin{array}{l}\text { Students got into seven groups of two or three. } \\
\text { They prepared a presentation on the character of } \\
\text { great figures }\end{array}$ \\
\hline
\end{tabular}




\section{REFERENCES}

[1] He Hua.The Application of Theme-base Teaching Approach in the College English Teaching[J].Journal of yulin normal university,2009(6).

[2] Liu Xiaoyi.The practice and thiking of college English theme-base teaching[J].Read and Write Periodical, 2009.

[3] Zhao Yan.Probe into Subject-Discussion Teaching Method of College English[J].Theory and Practice of Education, 2009 (29).
[4] Fudan University, Shanghai Jiao Tong University. Twenty-first century college English(Book Two).Higher Education Press, Fudan University Press, 2005.

[5] Haines S. Projects for the EFL classroom[J].Thomas Nelson and Ltd,1989

[6] GaoGuifang.On the "Sthdents-Centered And Subject-Focused Teaching Pattern” [J].Joural of Hengshui Normal College,2004(6).

[7] Recep Sahin Arsian. Teaching English to Science students via Themebased Model of Content-Based Instruction[J]. Turkish Science Education, 2010. 